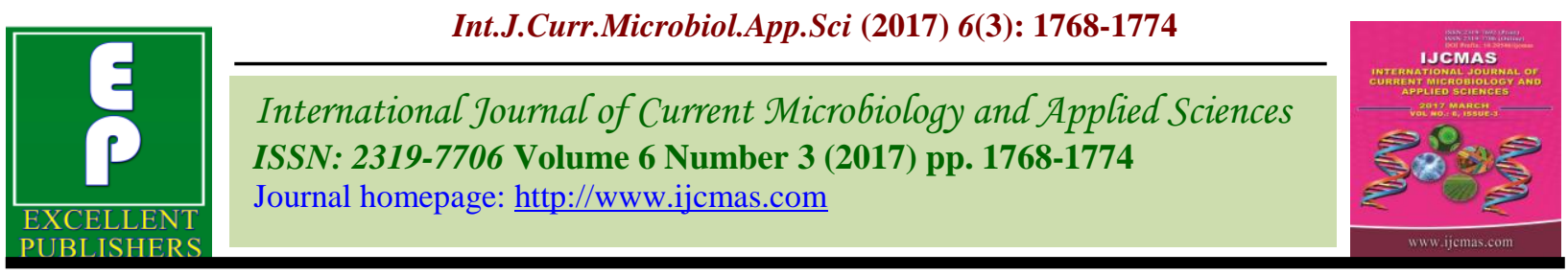

Original Research Article https://doi.org/10.20546/ijcmas.2017.603.203

\title{
Influence of Sulphur and Zinc Fertilization on Yield Attributes, Yield and Economics of Coriander Varieties
}

\author{
Madhuri Meena A.C. Shivran, P. Deewan and R. Verma* \\ S.K.N. College of Agriculture (S. K. N. Agriculture University), Jobner, 303 329, \\ Rajasthan, India \\ *Corresponding author
}

\begin{abstract}
A B S T R A C T
The present study was aimed to examine the effect of two varieties, four levels of sulphur $(0,20,40$ and $60 \mathrm{~kg} \mathrm{~S} / \mathrm{ha})$ and four levels of zinc $(0,2.5,5.0$ and $7.5 \mathrm{~kg} \mathrm{Zn} / \mathrm{ha})$ making 32

Keywords

Coriander,

Varieties,

Yield and

Economics.

Article Info

Accepted:

24 February 2017

Available Online:

10 March 2017 treatment combination under split plot design with three replications. Results showed that significantly increased umbels/plant, umbellets/umbel, seeds/umbel, seed (1409 kg/ha), stover and biological yields, and net returns (Rs 39396/ha) were obtained with coriander variety $\mathrm{RCr}-436$ as compared to variety $\mathrm{RCr}-435$. The variety $\mathrm{RCr}-436$ recorded 13.1 and $24.2 \%$ higher seed yield and net returns as compared to RCr-435. Sulphur application at $40 \mathrm{~kg} / \mathrm{ha}$ significantly increased umbels/plant, umbellets/umbel, seeds/umbel and test weight, seed (1406 kg/ha), stover and biological yields, and net returns (39175/ha) over control and $20 \mathrm{~kg} \mathrm{~S} / \mathrm{ha}$. The sulphur at $40 \mathrm{~kg} / \mathrm{ha}$ register 20.8 and $7.5 \%$ higher seed yield, 39.0 and $12.7 \%$ more net return over control and $20 \mathrm{~kg} / \mathrm{ha}$, respectively. Significantly increased umbels/plant, umbellets/umbel, seeds/umbel and test weight, seed (1436 kg/ha), stover and biological yields, and net returns (Rs. 39309/ha) were obtained with $5.0 \mathrm{~kg}$ $\mathrm{Zn} / \mathrm{ha}$ over control and $2.5 \mathrm{~kg} \mathrm{Zn} / \mathrm{ha}$. Zinc application@ $5.0 \mathrm{~kg} / \mathrm{ha}$ recorded significantly more seed yield by 30.3 and $10.5 \%$ and net returns by 35.2 and $10.4 \%$, respectively.
\end{abstract}

\section{Introduction}

Coriander (Coriandrum sativum L.) popularly known as "dhania" is one of the oldest seed spice used by the mankind. It is the most widely used condiment throughout the world. It is mainly grown for its aromatic and fragrant seed which is botanically a cremocarpic fruit. The fresh green stem, leaves and fruits of coriander have a pleasant aromatic odour. The pleasant aroma in the plant is due to an essential oil called "coriandrol" ranges from 0.1 to 1.3 per cent in dry seeds. The oil of coriander seeds is a valuable ingredient in perfumes, cosmetic products, soup, candy, cocoa, chocolate, meat products, soft drinks and alcoholic beverages.
Good quality oleoresin can be extracted from coriander seed which is used for flavouring beverages, sweets pickles, sausages, shacks etc. Coriander bark oil has high germicidal activity and can be used as fungicides (Krishna, 1999). The entire young plant is used for flavouring curried dishes of all sorts and chutney. Coriander leaves are also rich source of vitamin $\mathrm{C}(125-250 \mathrm{mg} / 100 \mathrm{~g})$ and vitamin A (5200 IU/100g). In medicines, its seed is used as a carminative, refrigerant and diuretic. The dry seeds of coriander contain 0.3 per cent essential oil, 19.6 per cent nonvolatile oil, 24 per cent carbohydrates, 5.3 per cent mineral matter and $175 \mathrm{IU} / 100$ vitamin A 
Recently sulphur deficiency has been aggravated in soils due to continuous crop removal under intensive cropping system and use of sulphur free high analysis NPK fertilizers. Sulphur which has now emerged as the third most important plant nutrient for crop plays a multiple role in nutrition. It helps in chlorophyll formation and also a constituent of amino acids like cystine, cysteine and methionine. Sulphur is also responsible for synthesis of certain vitamins (biotin and thiamine), proteins, fats and metabolism of carbohydrates (Tondon, 1991). Zinc is most deficient among all the micronutrients in Indian soils. In many parts of India, zinc as a plant nutrient now stands third in importance next to nitrogen and phosphorus (Takkar and Randhawa, 1980). It is a constituent of several enzyme systems which regulates various metabolic reactions in plant, for example oxidation reduction reactions in the formation of chlorophyll etc. It acts as an activator of dehydrogenase and proteinage enzymes directly or indirectly in the synthesis of carbohydrates and protein. Therefore, the present investigation carried out to study the effect of sulphur and zinc on yield, nutrient uptake and quality of coriander varieties.

\section{Materials and Methods}

The two year field experiment comprising 32 treatment combinations replicated three timeds, was laid out in split split design with two varieties (RCr-435 and $\mathrm{RCr}-436)$ and four levels of sulphur $(0,20,40$ and $60 \mathrm{~kg} / \mathrm{ha})$ in main plots and four level of zinc $(0,2.5$, 5.0 and $7.5 \mathrm{~kg} / \mathrm{ha}$ ) in sub plots. It was conducted at S.K.N. College of Agriculture, Jobner (Rajasthan) during rabi seasons of 2012-13 and 2013-14 situated at latitude of 27 ${ }^{0} 05^{\prime} \mathrm{N}$, longitude of $75^{\circ} 28^{\prime} \mathrm{E}$ and at an altitude of $427 \mathrm{~m}$ above mean sea level. The soil of experimental field was loamy sand, low in organic carbon $(0.18 \%)$, available $\mathrm{N}$
(128.4 kg/ha), phosphorus (17.18 kg/ha), zinc $(0.43 \mathrm{ppm})$ and medium in potassium $(173.40$ $\mathrm{kg} / \mathrm{ha}$ ) with alkaline $(\mathrm{pH}$ 8.4) in reaction having $1.60 \mathrm{Mg} / \mathrm{m}^{3}$ bulk density, $2.63 \mathrm{Mg} / \mathrm{m}^{3}$ particle density, $11.95 \%$ field capacity and $42.35 \%$ porosity at the beginning of the experiment. The crop variety $\mathrm{RCr}-436$ and $\mathrm{RCr}-435$ were sown in rows $30 \mathrm{~cm}$ apart with seed rate of $12 \mathrm{~kg} / \mathrm{ha}$. Uniform dose of nitrogen $(60 \mathrm{~kg} / \mathrm{ha})$ through urea and phosphorus (40 kg/ha), potassium $(20 \mathrm{~kg} / \mathrm{ha})$ and soil application of zinc and sulphur as per treatments through MOP, DAP, zinc chloride and gypsum, respectively were drilled at the time of sowing. During the crop season need based cultural and plant protection operations were taken up to harvest good crop during both the years of experimentation. Five random plants were selected from each plot for taking observations on yield attributes and for yield, the net plots were harvested. To ascertain the economic feasibility of different treatments, economics of treatments was worked out on the basis of prevailing market prices of inputs and outputs and expressed in terms of net profit per hectare so that most remunerative treatment could be recommended. Regular analysis of variance was performed for each trait for both the seasons and the pooled analysis over seasons after testing error variance homogeneity was carried out according to the procedure outlined by (Gomez and Gomez, 1984).

\section{Results and Discussion}

\section{Yield attributes and yield}

Coriander variety $\mathrm{RCr}-436$ recorded significantly higher umbels/plant, umbellets /umbel, seeds/umbel over variety RCr-435 during both the years of experimentation and in pooled data (Table 1). The per cent increase in umbels/plant, umbellets/umbel and seeds/umbel was $9.1,8.5$ and $10.4 \%$ by RCr435 , respectively on pooled mean basis. The 
marked increase in yield attributes under $\mathrm{RCr}$ 436 might be due to its genetic potential when grown under semi-arid conditions and improved growth of plants at successive stages as reflected by higher production of dry matter per plant at harvest. This subscribes to the view that there was adequate supply of metabolites in $\mathrm{RCr}-436$ as compared to $\mathrm{RCr}$ 435 for growth and development of reproductive structures (AICRPS, 2008). The variety of RCr-436 produced significantly higher seed $(1409 \mathrm{~kg} / \mathrm{ha})$, stover $(2061 \mathrm{~kg} / \mathrm{ha})$ and biological (3469 kg/ha) yields during both the years of experimentation and in pooled analysis and registered an increase of 13.1, 8.3 and $10.2 \%$ higher seed, stover and biological yield over RCr-435, respectively on pooled mean basis. Since coriander yield formation is a complex process and governed by interaction between source (photosynthesis and availability of assimilates in leaves etc.) and sink component (storage organs). Thus, as a consequence of marked improvement in both these regulative processes as evidenced from higher accumulation of biomass and nutrients as well as yield components in varieties RCr-436 led to significant increase in seed, stover and biological yields (Balai and Keshwa, 2010).

Increasing levels of sulphur at $40 \mathrm{~kg} / \mathrm{ha}$ recorded significant improved yield attributes of coriander viz., umbels/plant, umbellets/umbel, seeds/umbel in individual years of experiment as well as in pooled analysed data (Table 1). Application of sulphur at $40 \mathrm{~kg} / \mathrm{ha}$ during 2012-13 and 60 $\mathrm{kg} / \mathrm{ha}$ during 2013-14 significantly enhanced the test weight of coriander over control. On pooled basis, the application of $40 \mathrm{~kg} \mathrm{~S} / \mathrm{ha}$ increased umbels/plant by $23.2,8.2 \%$, umbellets/umbel by $20.1, \quad 6.8 \%$ and seeds/umbel by $21.7,7.3 \%$, respectively over control and $20 \mathrm{~kg} \mathrm{~S} / \mathrm{ha}$. The test weight was increased by $3.2 \%$ with application of $40 \mathrm{~kg}$ $\mathrm{S} /$ ha over control in pooled data. Supply of sulphur in adequate and appropriate amount helps in flower primordial initiation for its reproductive part. When supply of sulphur is optimum, greater translocation of photosynthates occurs from leaves towards sink i.e., yield attributes (Nawange et al., 2011). Application of sulphur @ 40 kg/ha increased seed (1406 kg/ha), stover (2075 $\mathrm{kg} / \mathrm{ha}$ ) and biological (3481 kg/ha) yields of coriander during both the year and in pooled data. The per cent increase in seed, stover and biological due to $40 \mathrm{~kg} \mathrm{~S} / \mathrm{ha}$ was recorded to the tune of $20.8,16.5$ and $18.2 \%$ over control and $7.5,6.3$ and $6.8 \%$ over $20 \mathrm{~kg} / \mathrm{ha}$, respectively. The seed, stover and biological yields primarily being a function of cumulative response of growth and yield attributing characters increased remarkably with increase in sulphur levels (Patel et al., 2013).

Application of successive dose of zinc upto 5 $\mathrm{kg} / \mathrm{ha}$ significantly increased the yield attributes viz., umbels/plant, umbellets/umbel and seeds/umbel during both the year as well as in pooled analysed data (Table 1). Application of zinc upto $2.5 \mathrm{~kg} / \mathrm{ha}$ recorded significantly enhanced test weight of coriander over control during both the years and in pooled mean. On pooled basis, the application of $5 \mathrm{~kg} \mathrm{Zn} / \mathrm{ha}$ increased umbels/plant by $25.8,9.2 \%$, umbellets/umbel by $28.4,9.5 \%$, seeds/umbel by $25.4,8.8 \%$ over control and $2.5 \mathrm{~kg} \mathrm{Zn} / \mathrm{ha}$ and the increase in test weight due to $2.5 \mathrm{~kg} / \mathrm{ha}$ was to the tune of $4.8 \%$ over control on pooled data, respectively. The increase in yield attributes might be due to role of zinc in biosynthesis of indole acetic acid (IAA) and especially due to its role in initiation of primordial for reproductive parts and partitioning of photosynthates towards them. Zinc is also an essential component of enzymes that are responsible for assimilation of nitrogen leading to higher growth and yield contributing parameters. 
Table.1 Effect of variety, sulphur and zinc fertilization on yield attributes of coriander

\begin{tabular}{|c|c|c|c|c|c|c|c|c|c|c|c|c|}
\hline \multirow[t]{2}{*}{ Treatments } & \multicolumn{3}{|c|}{ Umbels/plant } & \multicolumn{3}{|c|}{ Umbellets/umbel } & \multicolumn{3}{|c|}{ Seeds/umbel } & \multicolumn{3}{|c|}{ Test weight (g) } \\
\hline & $2012-13$ & 2013-14 & Pooled & 2012-13 & 2013-14 & Pooled & $2012-13$ & 2013-14 & Pooled & 2012-13 & 2013-14 & Pooled \\
\hline \multicolumn{13}{|l|}{ Variety } \\
\hline $\mathrm{RCr}-435$ & 20.27 & 18.50 & 19.38 & 5.41 & 4.89 & 5.15 & 24.85 & 24.41 & 24.63 & 9.81 & 9.92 & 9.87 \\
\hline RCr-436 & 22.07 & 20.21 & 21.14 & 5.88 & 5.30 & 5.59 & 27.58 & 26.79 & 27.19 & 10.07 & 10.16 & 10.11 \\
\hline SEm \pm & 0.23 & 0.25 & 0.17 & 0.06 & 0.06 & 0.04 & 0.33 & 0.34 & 0.23 & 0.12 & 0.12 & 0.08 \\
\hline $\mathrm{CD}(\mathrm{P}=0.05)$ & 0.71 & 0.75 & 0.52 & 0.19 & 0.21 & 0.14 & 0.99 & 1.02 & 0.72 & NS & NS & NS \\
\hline \multicolumn{13}{|c|}{ Sulphur levels (kg/ha) } \\
\hline 0 & 18.32 & 16.69 & 17.51 & 4.96 & 4.48 & 4.72 & 22.73 & 22.42 & 22.58 & 9.56 & 9.67 & 9.62 \\
\hline 20 & 20.86 & 19.05 & 19.95 & 5.59 & 5.03 & 5.31 & 25.89 & 25.28 & 25.59 & 9.90 & 9.96 & 9.93 \\
\hline 40 & 22.52 & 20.63 & 21.58 & 5.94 & 5.40 & 5.67 & 27.88 & 27.06 & 27.47 & 10.10 & 10.23 & 10.17 \\
\hline 60 & 22.97 & 21.04 & 22.01 & 6.09 & 5.48 & 5.79 & 28.36 & 27.65 & 28.00 & 10.19 & 10.30 & 10.25 \\
\hline SEm \pm & 0.33 & 0.35 & 0.24 & 0.09 & 0.09 & 0.06 & 0.46 & 0.48 & 0.33 & 0.17 & 0.17 & 0.12 \\
\hline $\mathrm{CD}(\mathrm{P}=0.05)$ & 1.01 & 1.06 & 0.74 & 0.26 & 0.27 & 0.19 & 1.39 & 1.44 & 1.02 & 0.51 & 0.51 & 0.37 \\
\hline \multicolumn{13}{|c|}{ Zinc levels (kg/ha) } \\
\hline 0 & 18.00 & 16.50 & 17.25 & 4.72 & 4.29 & 4.51 & 22.32 & 21.97 & 22.15 & 9.42 & 9.63 & 9.53 \\
\hline 2.5 & 20.77 & 18.97 & 19.87 & 5.57 & 5.01 & 5.29 & 25.78 & 25.27 & 25.53 & 9.90 & 10.07 & 9.99 \\
\hline 5.0 & 22.66 & 20.74 & 21.70 & 6.09 & 5.48 & 5.79 & 28.07 & 27.47 & 27.77 & 10.17 & 10.20 & 10.19 \\
\hline 7.5 & 23.24 & 21.21 & 22.23 & 6.21 & 5.61 & 5.91 & 28.69 & 27.70 & 28.20 & 10.26 & 10.26 & 10.26 \\
\hline SEm \pm & 0.30 & 0.31 & 0.22 & 0.08 & 0.09 & 0.06 & 0.39 & 0.40 & 0.28 & 0.13 & 0.13 & 0.09 \\
\hline $\mathrm{CD}(\mathrm{P}=0.05)$ & 0.87 & 0.89 & 0.61 & 0.24 & 0.25 & 0.17 & 1.11 & 1.14 & 0.78 & 0.37 & 0.37 & 0.26 \\
\hline
\end{tabular}


Table.2 Effect of variety, sulphur and zinc fertilization on yield and economics of coriander

\begin{tabular}{|c|c|c|c|c|c|c|c|c|c|c|c|c|}
\hline \multirow[t]{2}{*}{ Treatments } & \multicolumn{3}{|c|}{ Seed yield (kg/ha) } & \multicolumn{3}{|c|}{ Stover yield (kg/ha) } & \multicolumn{3}{|c|}{ Biological yield (kg/ha) } & \multicolumn{3}{|c|}{ Net returns (Rs/ha) } \\
\hline & 2012-13 & 2013-14 & Pooled & 2012-13 & 2013-14 & Pooled & 2012-13 & 2013-14 & Pooled & 2012-13 & 2013-14 & Pooled \\
\hline \multicolumn{13}{|l|}{ Variety } \\
\hline $\mathrm{RCr}-435$ & 1298 & 1193 & 1245 & 1960 & 1845 & 1902 & 3258 & 3038 & 3148 & 34211 & 29235 & 31723 \\
\hline $\mathrm{RCr}-436$ & 1465 & 1352 & 1409 & 2107 & 2015 & 2061 & 3572 & 3367 & 3469 & 42020 & 36772 & 39396 \\
\hline SEm \pm & 17 & 15 & 11 & 25 & 23 & 17 & 44 & 41 & 30 & 496 & 516 & 358 \\
\hline $\mathrm{CD}(\mathrm{P}=0.05)$ & 53 & 45 & 35 & 75 & 71 & 52 & 135 & 125 & 94 & 1506 & 1566 & 1104 \\
\hline \multicolumn{13}{|c|}{ Sulphur levels (kg/ha) } \\
\hline 0 & 1210 & 1118 & 1164 & 1831 & 1731 & 1781 & 3041 & 2850 & 2945 & 30347 & 26007 & 28177 \\
\hline 20 & 1362 & 1254 & 1308 & 2007 & 1897 & 1952 & 3369 & 3152 & 3260 & 37310 & 32230 & 34770 \\
\hline 40 & 1464 & 1347 & 1406 & 2132 & 2018 & 2075 & 3597 & 3365 & 3481 & 41923 & 36428 & 39175 \\
\hline 60 & 1489 & 1370 & 1430 & 2162 & 2074 & 2118 & 3652 & 3444 & 3548 & 42882 & 37349 & 40116 \\
\hline SEm+ & 25 & 21 & 16.08 & 35 & 34 & 25 & 63 & 58 & 43 & 702 & 730 & 506 \\
\hline $\mathrm{CD}(\mathrm{P}=0.05)$ & 74 & 63 & 50 & 106 & 100 & 74 & 191 & 177 & 132 & 2129 & 2215 & 1561 \\
\hline \multicolumn{13}{|c|}{ Zinc levels (kg/ha) } \\
\hline 0 & 1156 & 1048 & 1102 & 1759 & 1657 & 1708 & 2915 & 2705 & 2810 & 31601 & 26537 & 29069 \\
\hline 2.5 & 1351 & 1246 & 1299 & 1994 & 1892 & 1943 & 3345 & 3138 & 3242 & 38058 & 33129 & 35594 \\
\hline 5.0 & 1490 & 1381 & 1436 & 2168 & 2056 & 2112 & 3658 & 3437 & 3548 & 41874 & 36745 & 39309 \\
\hline 7.5 & 1529 & 1415 & 1472 & 2212 & 2115 & 2164 & 3741 & 3530 & 3636 & 40929 & 35605 & 38267 \\
\hline SEm \pm & 23 & 19 & 15.40 & 33 & 32 & 23 & 53 & 53 & 38 & 619 & 602 & 432 \\
\hline $\mathrm{CD}(\mathrm{P}=0.05)$ & 67 & 55 & 43 & 99 & 93 & 67 & 150 & 151 & 105 & 1760 & 1711 & 1211 \\
\hline
\end{tabular}


These findings of present investigation are supported by Yousuf et al., (2014) in coriander. The further pooled data analysis of present experiment indicated that application of $5 \mathrm{~kg} \mathrm{Zn} / \mathrm{ha}$ significantly increased seed $(1436 \mathrm{~kg} / \mathrm{ha})$, stover $(2112 \mathrm{~kg} / \mathrm{ha})$ and biological $(3548 \mathrm{~kg} / \mathrm{ha})$ yields of coriander during both the years as well as in pooled analysis and represented an increased seed by 30.3 and 10.5 per cent in seed, 23.3 and 8.7 per cent in stover and 26.3 and 9.4 per cent in biological yields over control and $2.5 \mathrm{~kg}$ $\mathrm{Zn} / \mathrm{ha}$, respectively. The applied as well as native zinc helped to improve overall availability in the rhizosphere resulting into greater uptake by the plant consequently leading to a favourable stimulus effect on physiological and metabolic processes of the plant (Chauhan et al., 2013).

\section{Economics}

The data (Table 2) indicated that variety $\mathrm{RCr}$ 436 recorded higher net returns of Rs. 39396/ha, representing an increase of Rs. 7673/ha over RCr-435 (Rs 31723/ha). Despite the same cost of cultivation for both the varieties, the higher seed yield recorded under variety $\mathrm{RCr}-436$ have led to increased net returns as compared to $\mathrm{RCr}-435$. These results are also supported by the findings of Balai and Keshwa (2010). The net returns (Rs.39175/ha) were increased significantly with increasing levels of sulphur upto 40 $\mathrm{kg} / \mathrm{ha}$ by ${ }^{`} 10998$ and 4405/ha over control and $20 \mathrm{~kg} \mathrm{~S} / \mathrm{ha}$, respectively (Table 2). This was mainly due to the increased seed yield with comparatively lesser cost of sulphur under this treatment. Similar results were also reported by Lal et al., (2014). The economic evolution (Table 2) shows that in coriander, the application of zinc at the rate of $5.0 \mathrm{~kg} / \mathrm{ha}$ exhibited maximum net returns (Rs.39309/ha) which was significantly higher by Rs. 10240 and Rs. 3715 over control and $2.5 \mathrm{~kg} \mathrm{Zn} / \mathrm{ha}$, respectively. The cost involved under the treatment was comparatively lower than its additional income due to high yield, which led to more returns under these treatments. These results also substantiated by Lal et al., (2014).

\section{References}

AICRPS, 2008. Annual Report, 2007-08. All India Co-ordinated Research Project on Spices, S.K.N. College of Agriculture, Jobner.

Balai, L.R. and Keshwa, G.L. 2010 Effect of thiourea on yield and economic of coriander (Coriandrum sativum L.) varieties under normal and late sowing condition. J. progressive Agri., 1(1): 5255.

Balai, L.R. and Keshwa, G.L. 2011. Effect of thiourea on yield and nutrient uptake of coriander (Coriandrum sativum L.) varieties under normal and late sowing conditions. J. Spices and Aromatic Crops, 20(1): 34-37.

Chauhan, T.M., Singh, S.P. and Ali, J. 2013. Differential Response of wheat cultivars to zinc application in alluvial soil. Annals of Plant and Soil Res., 15(2): 152-155.

Gomez, Kwanchai, A. and Gomez, Arturo, A. 1984. Statistical procedures for agricultural research. $2^{\text {nd }}$ Edition, International Rice Research Institute. Hohn Willy and sons, New York, chicester, Brisbane, Toronto, Singapore pp. 20-134.

Jakhar, R.K., Yadav, B.L. and Choudhary M.R. 2013. Irrigation water quality and zinc on growth and yield of fenugreek (Trigonella foenum- graecum L.). J. spices and Aromatic crops, Vol. 22(2): 170-173.

Jat, G., Majumdar, S.P. and Jat, N.K. and Mazumar, S.P. 2013. Potassium and zinc fertilization of wheat (Triticum aestivum) in western arid zone of India. Indian J. Agron., 8(1): 67-71. 
Krishna, A. 1999. Spice: Some known and unknown facts. Sci. Culture, 65: 220228.

Lal, G., Mehta. R.S., Maheria, S.P., and Sharma, Y. 2014. Influence of sulphur and zinc on growth and yield of coriander (Coriandrum sativum L.). Int. J. Seed Spices, 4(2): 32-35.

Mathur, M.L., Purohit, A.K., Meena, H.S. and Solanki, R.H. 2013. Effect of phosphorus and sulphur on yield, quality and nutrient uptake by chickpea (Cicer arietinum L.). Environ. Ecol., 31(1A): 325-327.

Nawange, D.D., Yadav, A.S. and Singh, R.V. 2011. Effect of phosphorus and sulphur application on growth, yield attributes and yield of chickpea (Cicer arietinum L.). Legume Res., 34(1): 48-50.

Patel, C.B., Amin, A.U. and Patel, A.L. 2013. Effect of varying levels of nitrogen and sulphur on growth and yield of coriander (Coriandrum sativum L.). An Int. Quarterly J. Life Sci., 8(4): 12851289.

Said-al ahi, H.A.H. and Omer, E.A. 2009. Effect of spraying with zinc and / or iron on growth and chemical composition of coriander (Coriandrum sativum L.) harvested at three stages of development. J. Med. Food Plants, 1(2): 30 .

Takkar, P.N. and Randhawa, N.S. 1980. Zinc deficiency in Indian soils and plants. Seminar on zinc wastes and their utilization, 15-18, Oct. organized by Indian lead zinc information center and the fertilizer Association of India, New Delhi.

Tondon, H.L.S. 1991. Sulphur research and agricultural production in India. pp. 4775.

Verma, A., Pandeya, S.N., Yadav, S.K., Singh, S. and Soni, P. 2011. A review of Coriandrum satvium (Linn.). An Ayurvedic medicinal herbs of Happiness. J. Pharmacy and Healthcare Res., 1(3): 28-48.

Yousuf, M.N., Brahma, S., Kamal, M.M., Akter and Choudhary, M.E.K. 2014. Effect of nitrogen, phosphorus, potassium and sulphur on the growth and seed yield of coriander (Coriandrum sativum L.). Bangladesh J. Agri. Res., 39(2): 303-309.

\section{How to cite this article:}

Madhuri Meena A.C. Shivran, P. Deewan and Verma, R. 2017. Influence of Sulphur and Zinc Fertilization on Yield Attributes, Yield and Economics of Coriander Varieties. Int.J.Curr.Microbiol.App.Sci. 6(3): 1768-1774. doi: https://doi.org/10.20546/ijcmas.2017.603.203 